\title{
Revista
}

(Rgp)) Gestão \& Políticas Públicas

Artigo

\section{O jeitinho brasileiro: traço da identidade nacional?}

The Brazilian way: feature of national identity?

El estilo brasileño: característica de la identidad nacional?

Lisete Barlach ${ }^{1}$,

\footnotetext{
${ }^{1}$ Filiação institucional. Doutora pelo Programa de Pós-Graduação em Psicologia Social, pesquisadora do Grupo de Estudos e Pesquisas em Psicologia Política, Políticas Públicas e Multiculturalismo e docente da Escola de Artes, Ciências e Humanidades da Universidade de São Paulo, São Paulo, SP, Brasil.

Correspondência: E-mail: lisbar@usp.br
}

Resumo Ao olhar o Brasil com olhos de estrangeiros (as), é possível constatar a existência de traços culturais peculiares, componentes da identidade nacional. Situado entre a criatividade e a corrupção, um desses traços o jeitinho brasileiro - tem sido retomado como objeto de estudo em função da reorganização do mercado internacional do trabalho, com a discriminação positiva - ou valorização - dos profissionais brasileiros trabalhando no exterior e também pelo interesse despertado pelo Brasil como um dos países emergentes reunidos nos BRICS, que tem atraído estrangeiros (as) para trabalhar no País. O presente artigo consiste em uma revisão da literatura sobre o tema, considerando publicações entre 2010 e 2014, além de uma releitura das bases históricas sobre o assunto, como o trabalho seminal de Lívia Barbosa e os aportes de Da Matta, dentre outros. A atualidade do tema se manifesta na diversidade de interesses a ele associados identificados na literatura, incluindo o impacto do jeitinho na inovação tecnológica e competitividade industrial e sua influência na cola, plágio e outras práticas desonestas na vida acadêmica.

Palavras-chaves: Identidade nacional; "jeitinho" brasileiro; pessoa 
e indivíduo diante do Estado.

Abstract

Resumen
When looking at Brazil with foreign eyes, it is possible to observe the existence of quirky cultural traits, components of the national identity. Situated in-between creativity and corruption, one of those traits Brazilian "jeitinho" - has been taken as an object of study due to its relation with the reorganization of the international labor market, with positive discrimination of Brazilian professionals working abroad and also for the interest aroused by Brazil as one of the emerging countries gathered in the BRICS, attracting foreigners to work in the country. This article consists in a literature review of the topic, considering publications between 2010 and 2014, plus a re-reading of historical bases on the subject, as the seminal work of Livia Barbosa and Da Matta, among others. The actuality of the theme is manifested through the diversity of associated interests identified in the literature, including the impact of the "jeitinho" in technological innovation and industrial competitiveness and its influence on glue, plagiarism and other dishonest practices on academic life.

Keywords: National identity; Brazilian "jeitinho"; person or individual facing the State.

Al mirar el Brasil con ojos extranjeros, es posible observar la existencia de rasgos culturales peculiares, componentes de la identidad nacional. Situado entre la creatividad y la corrupción, uno de los rasgos, el "jeitinho" brasileño, ha sido revivido como objeto de estudio en función de la reorganización del mercado laboral internacional, con la discriminación positiva de profesionales brasileños que trabajan en el extranjero y también por el interés despertado por el Brasil como uno de los emergentes países reunidos en los BRICS, que ha atraído a los extranjeros (as) para trabajar en el país. Este artículo consta de una revisión de la literatura sobre el tema, teniendo en cuenta las publicaciones entre 2010 y 2014, además de una relectura de bases históricas sobre el tema, como el trabajo seminal de Livia Barbosa y tomas de Da Matta, entre otros. La actualidad del tema se manifiesta en la diversidad de intereses que fueran identificados en la literatura, incluyendo el impacto de la manera en la innovación tecnológica y competitividad industrial y su influencia en pegamento, plagio y otras prácticas deshonestas en la vida académica.

Palabras Clave: Identidad nacional; "jeitinho" brasileiro; persona y individuo adelante del Estado

Palavras-chaves: Karl Marx. A Guerra Civil na França. Teoria da revolução. Estratégia política. Antiestatismo. 


\section{Introdução}

No Brasil, um não pode ser diferente do não com sentido negativo; ele pode significar talvez e, dependendo de um bom papo, pode se tornar um sim, como em muitas situações de relacionamentos cotidianos entre motoristas e guardas de trânsito, mencionados por Barbosa (2006). Dentre outras características, o jeitinho brasileiro encontra uma solução para aquilo que não tem solução, não sendo as leis, normas e a própria constituição nacional barreiras definitivas e irrevogáveis para o comportamento.

As manifestações empíricas do jeitinho, apoiadas por estudos antropológicos e literários, incitaram, há muito, a preocupação em definir a brasilidade. Sylvio Romero (1851-1914) e Euclydes da Cunha (1866-1909) são mencionados por Queiroz (1989) como precursores de reflexões sobre o patrimônio cultural brasileiro, revelando que as tentativas de compreensão das peculiaridades da identidade nacional brasileira remontam ao século XIX.

Queiroz (1989) afirma que muitas pesquisas das ciências sociais brasileiras no final do século 19 e início do século 20 alertavam para "a grande heterogeneidade de traços culturais ligados à variedade dos grupos étnicos que coexistiam no espaço nacional, [distribuídos] diversamente conforme as camadas sociais. [Estes] não configuravam de modo algum um conjunto harmonioso que uniria os habitantes, comungando as mesmas visões do mundo e da sociedade, ou orientações de comportamentos. Complexos culturais aborígenes, outros de origem europeia, outros ainda de origem africana, coexistiam". Na época, as análises entendiam a diversidade e miscigenação como "obstáculos [que impediriam] o Brasil de chegar ao esplendor da civilização europeia, [...] retardando o encaminhamento do país para a formação de uma verdadeira identidade nacional, [e isso] naturalmente embaraçava também um desenvolvimento econômico mais eficiente".

Na maneira de pensar dos intelectuais de então, a identidade nacional não podia existir sem certa homogeneidade de traços culturais, e, como encontravam na sua cultura grandes disparidades, o pessimismo era dominante em seus trabalhos. Somente podiam conceber uma identidade cultural da maneira que julgavam ser a ocidental - branca, educada, refinada. (Queiroz, 1989, p. 21).

Posteriormente, o sincretismo cultural passou a ser muito importante no pensamento sociológico brasileiro, pois, se os intelectuais brasileiros persistissem em desprezar os traços culturais aborígenes e africanos, anulariam os únicos elementos que tornavam sua civilização única entre as demais do globo. "Se continuassem a se apresentar como europeus, e, - pior ainda, - como europeus de qualidade inferior porque possuidores de uma cultura mestiça, recheada de traços bárbaros, - continuariam negando a existência da identidade nacional. A única forma de [lidar com isso] era dando ênfase e atribuindo maior valor à heterogeneidade da civilização nacional" (Queiroz, 1989, p. 26). 
A definição da identidade nacional envolvia a busca de uma característica comum que definisse as coletividades ou aquilo que todos os membros partilhavam como patrimônio cultural, dando origem a um conjunto de valores e de crenças que os tornavam sui generis.

Uma vez que o presente artigo investiga o jeitinho brasileiro como um dos traços da identidade nacional, procede-se, incialmente, à revisão histórica da temática.

\section{Histórico dos Estudos Sobre a Brasilidade}

Quando os estudiosos brasileiros, na segunda metade do século XIX, iniciaram debates sobre a existência ou não de sua identidade, questão similar já estava sendo discutida por mais de um século por intelectuais europeus. Haviam estes tentado identificar as qualidades específicas de grupos étnicos e culturais - catalães, bretões, napolitanos, etc. — tanto no que dizia respeito a qualidades físicas, quanto a peculiaridades psicológicas. Nascera destas preocupações uma nova ciência na segunda metade do século XIX, ou mais precisamente em 1859 - a "Völkerpsychologie", na Alemanha: a "Folk Psychology", na Inglaterra; a "Psychologie des Peuples", na França. (Queiroz, 1989, p. 27)

Queiroz (1989) afirma que a orientação de tais estudos era de natureza psicológica, e sua finalidade, descobrir quais virtudes, e defeitos, constantes no tempo, davam a cada grupo étnico sua personalidade e o tornavam reconhecível no meio de outros (Queiroz, 1989, p. 27).

Segundo ela, "Raymundo Nina Rodrigues foi o grande iniciador dos estudos de etnografia e de psicologia social no país. Aliás, foi ele também, na Europa e mais especialmente na França, um dos fundadores da Psicologia das Multidões, ao lado dos Sighele, dos Rossi, dos Tarde e dos Le Bon. Mas enquanto os europeus efetuavam estudos teóricos, partia ele para estudos de campo sobre material diretamente observado e colhido na Bahia, contrapondo-se a seus colegas europeus, mostrando que conceitos e definições destes não se adequavam a casos brasileiros". Para a autora, "até hoje seus trabalhos são um precioso repositório de dados, principalmente relativos às religiões afrobrasileiras" (Queiroz, 1989, p. 19).

"O racismo estava [...] presente nos trabalhos destes pesquisadores do século XIX, envolto, em doses variadas, com o pessimismo pelo futuro econômico e cultural do país, assim como pela negação da existência de características especificamente brasileiras, e até mesmo da possibilidade de formação [de uma identidade nacional] um dia", como anteriormente mencionado (Queiroz, 1989, p. 19). 
O escritor e ensaísta Oswald de Andrade (1890-1954), forjando a teoria da antropofagia, representou um marco diferencial para com esta tendência, explicando como se operava a fusão dos elementos culturais díspares: "o Brasil, culturalmente, devora as civilizações que a ele vêm ter, compondo uma nova totalidade diferente das anteriores" (Queiroz, 1989, p. 22).

A partir daí, novos estudos revelaram que, forçados a se misturar, os elementos heterogêneos foram vistos como garantia de originalidade e beleza à nova cultura proveniente e resultante da própria incongruência dos traços, coagidos a se ajustarem uns aos outros no interior de um mesmo conjunto. Nestes arranjos numa outra configuração, com outro sentido, se encontrava a especificidade da civilização brasileira dentre as nações (Queiroz, 1989, p. 22).

A criatividade, conforme Barlach (2009) pode resultar da combinação de elementos ou da percepção de novas configurações dos mesmos elementos. Supõe-se que, quanto mais díspares os componentes, maior será a criatividade da resultante, o que poderia explicar uma das vertentes do jeitinho brasileiro, a saber, a enorme criatividade associada à brasilidade. Esse assunto será retomado adiante, quando da análise do jeitinho brasileiro propriamente dito.

Dando sequência à elaboração histórica da identidade cultural brasileira, Queiroz (1989) refere-se à onda de imigração estrangeira, "que se avolumara nos últimos anos do século XIX, persistiu durante as primeiras décadas do século XX; e pelos anos 10 e 20, alguns dos recém-chegados e seus descendentes já haviam se alçado a estratos mais elevados da hierarquia socioeconômica e até política, atingindo mesmo posições importantes na administração pública". Essa miscigenação acrescentou ainda mais elementos ao manancial criativo já mencionado, que será analisado adiante.

Quando Livia Barbosa (2005) afirma que o jeitinho é um ritual que transforma indivíduos em pessoas (p. 103) e que o "você sabe com quem está falando?" indica a necessidade de um tratamento "personalizado", não submetido a leis universalizantes e impessoais, é possível formular uma hipótese de que a origem destes traços seja a ascensão social dos recém-chegados e seus descendentes, referida por Queiroz. Enquanto o desejo de ter o indivíduo como valor é a representação social central da sociedade ocidental (Barbosa, 2005, p. 112), o personagem simetricamente oposto ao indivíduo, típico das sociedades tradicionais, holistas, é a pessoa (Barbosa, 2005, p. 113). É, portanto, no encontro da sociedade tradicional com os imigrantes europeus que as características centrais do jeitinho teriam se estabelecido.

Ressalte-se que o conflito pessoa - indivíduo, base do jeitinho, também é explorado por Da Matta (1997), que afirma que "quem tiver sucesso acaba virando uma pessoa e sendo tratado de modo especial, diferente" (Da Matta, 1997, p. 237), corroborando a tese de Barbosa. 


\section{O jeitinho Brasileiro: a Tese de Lívia Barbosa}

Barbosa (2005) pode ser considerada precursora desse campo de estudos. Seu livro, datado de 1992, versão modificada de sua tese de doutorado, defendida em 1986, reflete um momento em que a Antropologia deixa de olhar apenas para povos "exóticos" ou "primitivos" e se volta para pesquisar a cultura na qual se está mergulhado. Tendo como marco histórico a Escola de Chicago, a etnografia, técnica por excelência da Antropologia, passa a estudar os significados da vida cotidiana na sociedade ocidental, exigindo deslocamento do pesquisador em relação à sua própria cultura, a transformação do familiar em exótico e do exótico em familiar, ou, em outras palavras, uma postura de negação do etnocentrismo.

Assim como Da Matta (1997), Barbosa busca ampliar a compreensão de traços característicos da identidade nacional brasileira, destacando o jeitinho como elemento descritor da brasilidade, seja ele usado como autoestereótipo nacional (Espinosa, 2010) ou auto atribuição de imagem (Barbosa, 2005), seja na comparação entre brasileiros e outros povos.

A partir de uma revisão dos cinco estudos conhecidos até 1996, Barbosa conclui que o que havia em comum entre todos eles era o elemento adaptativo que permeia a identidade social brasileira, se comparado o Brasil com outros países (Barbosa, 2005, p.28).

Outro aspecto curioso acerca da análise por ela procedida é a presença da ideia de que, se os povos primitivos deveriam ser estudados como ancestrais da humanidade que deram lugar a outros, numa evolução até as modernas organizações sociais (Pereira, 2008), também o Brasil do jeitinho desapareceria quando este se tornasse um país moderno, parametrando a modernidade pelo europeísmo e anglicanismo dominantes.

Na visão de Barbosa, o jeitinho não é conotado apenas negativamente, mas deve ser situado num continuum entre o favor e a corrupção, favor este que não envolve a transgressão de qualquer norma ou regra (p. 42). Sob o ponto de vista da Antropologia, trata-se de forma "especial" de resolver problemas ou situação difícil /proibida, ou, em outras palavras, apor uma solução criativa a um problema aparentemente sem solução (Barbosa, 2005, p.32).

Solicitar um favor, pedir a alguém para "quebrar um galho", ou propor um "jeitinho" são diferentes maneiras de expressar a pessoalidade em oposição à impessoalidade da relação Estado - indivíduo, característica da implantação do Estado Brasileiro nos moldes norte-americanos e europeus.

Em função do fato de que, no Brasil, o indivíduo tenha conotações negativas (Da Matta, 1979) e a pessoa seja assumida em seu aspecto positivo, o jeitinho brasileiro busca revalorizar a pessoa que está descaracterizada como 
indivíduo frente ao Estado. Nesse sentido, é comum a afirmação de que "aos amigos, tudo; aos inimigos, a lei", revelando o universo social dual do Brasil.

Da Matta (1979, in Barbosa, 2006, p. 115) afirma que

O Brasil seria uma sociedade sui generis, no sentido de que apresentaria múltiplos eixos ideológicos - no caso, a hierarquia e o individualismo - sem que nenhum dos dois fosse hegemônico nem competitivo. Eles seriam complementares. Ao contrário dos Estados Unidos, onde a sociedade é englobada por uma única ética - a individualista -, no Brasil conviveríamos com duas, apresentando um universo social complexo e fascinante. Nesse ambiente se desenrolaria o que o autor denomina "dilema brasileiro": a tensão permanente entre as categorias de indivíduo e pessoa.

Barbosa (2005, p. 115) entende, tomando por base o estudo de Da Matta (1979), que essa característica brasileira é fruto de um desenvolvimento histórico particular e suas aproximações com o mundo latino e católico.

O jeitinho, como um dos elementos da identidade social brasileira, é emblemático, congregando em si formas peculiares de perceber o Brasil e os (as) brasileiros (as), por privilegiar os aspectos humanos e naturais em detrimentos dos institucionais (p. 171), encarnando "nosso espírito cordial, conciliador, alegre, simpático, caloroso", [...], de um país tropical, bonito, sensual, jovem e cheio de possibilidades" (Barbosa, 2005, p. 172).

Esta característica é contrastada, em geral, com a leitura efetuada sobre os países anglo-saxões, como frios e rígidos. Nesse sentido, o jeitinho promove uma homogeneização positiva, anulando diversidades internas, enfatizando as qualidades do "povo" brasileiro.

Por outro lado, o jeitinho, como caraterística identitária, é também conotado de forma negativa, pois as "relações pessoais, uma vez estabelecidas, tomam precedência sobre qualquer outro critério; porque o cidadão brasileiro tem vários parentes próximos que não o deixam reinar sozinho em nosso ambiente social" (p. 174). Diante da afirmação do ex-presidente francês Charles De Gaulle, de que este não é um país sério, o jeitinho poderia indicar, segundo Barbosa, que a não seriedade se confirma porque "todos os parâmetros da ideologia individualista, consubstanciados num tratamento igualitário de todos perante a lei, são permanentemente vazados na prática social de vários domínios [...em função] da perspectiva relacional, que transforma o público em privado e, assim, torna legítimo o que seria espúrio sob aquela perspectiva".

Seria o estudo de Barbosa atual ou o Brasil já teria "superado" o jeitinho? Embora a pesquisa da autora date do final da década de 1990, constatou-se a atualidade do estudo de Barbosa sobre o jeitinho brasileiro no grande número de citações que aparecem na literatura mais recente, como se verá a seguir. 


\section{O Jeitinho Brasileiro: a Literatura Recente}

Em 90\% dos artigos compilados, há referências explícitas ao trabalho de Lívia Barbosa, sinalizando sua importância como obra-chave sobre a temática. Embora não se tome por critério a maior ou menor relevância dos estudos posteriores, serão apresentadas as inúmeras temáticas que se utilizam do estudo do jeitinho como parâmetro de compreensão de distintos aspectos da realidade social ou econômica do país.

Como mencionado anteriormente, a pesquisa que embasou o presente artigo foi de natureza bibliográfica, configurando-se como qualitativa e descritiva.

Com as palavras-chave "jeitinho brasileiro", utilizadas sempre em conjunto, foram identificados mais de 800 resultados no google acadêmico (www.scholar.google.com), tendo sido usado como filtro o período de 2010 a 2014. Destes, foram escolhidos nove, em função de sua representatividade, qualidade autoral e diversidade temática.

O primeiro deles trata da identidade cultural e nacional e foi incluído em função da abordagem histórica da natureza identitária brasileira (Queiroz, 1989). Já mencionado na introdução do presente trabalho, serviu como seu fio condutor, mesmo não fazendo menção direta ao jeitinho brasileiro. Utilizou-se como complemento da abordagem histórica o artigo de Vieira et. al. (1982), que discute o jeitinho como recurso de poder.

O segundo, de 2011, aborda a relação entre o jeitinho e a religiosidade popular, a partir do estudo do caso Vale do Amanhecer. Neste mesmo ano, Borges analisa a improvisação no jeitinho brasileiro referindo-se ao corpo em movimento, ou, em outras palavras, aos gestos corporais que expressam o caráter afetivo e pessoal de quem pede um jeitinho, improvisando meios de se relacionar com as instituições modernas, "em benefício da urgência pessoal e em detrimento das regras" (Borges, 2011, p. 134).

Em 2012 Gonzalez analisa o caminho da Anistia à Comissão da Verdade, a partir do jeitinho brasileiro. Em 2013, Pereira et al. estudaram a influência do jeitinho na fragilidade do cooperativismo brasileiro, analisando a interface entre a cultura organizacional e a nacional.

De 2014 é o texto de Souza et al., que discute o marketing informal como modelo de comercialização pautado em jeitinho brasileiro, informalidade e empreendedorismo. Também de 2014 é o artigo de Zawislak que aborda o impacto do jeitinho na gestão da inovação tecnológica e competitividade brasileira. A cola, o plágio e outras práticas acadêmicas desonestas é outro assunto com interface com o jeitinho, de acordo com Oliveira et al. (2014). O lado sombrio do jeitinho é analisado no artigo de Leichsenrin (2014) sob o título "A universidade corrupta: o jeitinho brasileiro de se fazer ciência". 
Cada um dos artigos será comentado a seguir, com o objetivo de alcançar uma visão compreensiva e abrangente do jeitinho brasileiro como elemento da identidade nacional do País. Em cada uma das análises, será destacada a conotação do jeitinho como criatividade ou corrupção.

\section{Vale do Amanhecer: Religião e Identidade}

O estudo de Ribeiro (2011) destaca a singularidade que a Nova Era assume no Brasil, tomando o Vale do Amanhecer como um caso emblemático, em que a articulação do discurso originário da Nova Era com a religiosidade popular brasileira se dá de forma mais clara, estando presente o jeitinho brasileiro em sua vertente criativa.

A Nova Era, no Brasil, ao sincretizar, realiza tal processo dentro de uma brasilidade, com o famoso jeitinho, falando em preto-velhos, caboclos, lemanjá, etc., incorporando o espiritismo kardecista, como um elemento fundamental para cimentar as práticas sincréticas, já que ele remete a uma religião de mediação, ao mesmo tempo próxima das práticas dos cultos afro-brasileiros, por ser uma religião de possessão, mas distante simbolicamente por ser uma religião de brancos e letrados (Ribeiro, 2011, p. 82).

Entendendo que tais práticas buscam viabilizar a abertura para outras possibilidades de arranjos e rearranjos, que se articulam de forma a construir uma realidade simbolicamente capaz de gerar sentido para os sujeitos envolvidos (Ribeiro, 2011, p. 89), o autor contribui com para a compreensão do sincretismo religioso de forma mais ampla, dizendo que o catolicismo aqui instaurado assumiu ares tropicais, incorporando elementos de sua realidade nas Américas, sendo possível identificar diferenças entre o catolicismo lbérico e o Brasileiro.

Acrescenta que a revelação de Nina Rodrigues acerca da continuidade, por mais de três séculos, das religiões africanas sob a máscara de uma adesão superficial ao catolicismo, cultos que mantinham estranhas maneiras de pensar e de agir, parecendo abalar a moral existente, e cujo poder sobrenatural era difícil negar ou medir (Queiroz, 1989), pode explicar que não só o catolicismo incorporou elementos; eles transbordaram para as demais práticas religiosas, sendo emblemático o caso das religiões afro-brasileiras, em que os orixás são mascados pelos santos católicos, num complexo jogo de analogias (Bastide, 1985 in Oliveira, 2011, p. 68).

Neste cenário, fica claro o quão diverso é o campo religioso brasileiro, desde a sua gênese. Oliveira chama a atenção para como as identidades se articulavam nesse período histórico, bem como o caráter singular que a vivência religiosa tomava naquele momento. Alerta para o fato de que não se pode negar que sempre houve conversões religiosas, forçadas ou não, criando uma identidade religiosa pública e outra privada, articuladas e porosas entre si (Oliveira, 2011, p. 71). 
O autor, ao estudar o caso do Vale do Amanhecer, explica que esta "seita", pertencente a uma corrente mais ampla denominada Nova Era, "surge em consonância a este ethos individualista moderno, que não exclui, em absoluto, a experiência comunitária, apenas realiza um giro em termos de possibilidades postas à esfera da subjetividade[...]. A Nova Era se caracteriza pela possibilidade de arranjar, desarranjar ou rearranjar elementos de tradições já existentes, e distintas, e se utilizar de tais elementos enquanto metáforas para expressar performaticamente uma dada visão, em determinado momento (Oliveira, 2011, p. 73).

No Vale do Amanhecer caboclos incorporam em médiuns, ao mesmo tempo que eles quando incorporados fazem referências a Iara, Iemanjá, Princesas Encantadas, Cavaleiros do Oriente, Dr. Fritz, Bezerra de Menezes etc. Imagens de índios, pretos velhos habitam pirâmides egípcias, juntamente com outras que lembram hindus, e outros que se apresentam como seres intergalácticos.

Diz o autor que "fala-se em preto-velhos, caboclos, lemanjá, etc., mas quando indagamos aos nossos informantes se estes são os mesmos daqueles encontrados na umbanda e no candomblé, eles enfaticamente destacam que não são, só se aparentam na imagem, mas são outros, seres de luz, evoluídos espiritualmente, que estão aqui para fazer caridade" (Oliveira, 2011, p. 81).

Em função das questões abordadas pelo autor, pode-se afirmar que o jeitinho brasileiro emerge em sua vertente criativa, embora caiba a ressalva quanto à possível corruptela - ou descaracterização - da originalidade de cada uma das religiões que se uniram no caso Vale do Amanhecer. O aprofundamento do estudo poderia revelar uma possível antropofagia, nos termos de Oswald de Andrade, conforme mencionado anteriormente, ou seja, um sincretismo que consome as especificidades de cada componente.

\section{Borges, a Improvisação e o Jeito do Corpo}

Referindo-se ao trabalho seminal de Barbosa (1992) sobre o jeitinho, Borges retoma a explicação do seu caráter híbrido entre pessoa e indivíduo (Borges, 2011, p. 135), lembrando que, do ponto de vista identitário nacional, "do indivíduo assimilamos o caráter generalizante, e da pessoa, o caráter afetivo". Para ela,

causam-nos estranheza a impessoalidade e a polidez genérica que caracterizam o modo de relacionamento nessas instituições. Procuramos sempre as pessoas que se escondem sob os números de inscrição, de identificação etc. Assim, o jeitinho acontece dentro dos ambientes institucionais cuja organização se apoia sobre as regras, mas estas são suspensas quando o apelo emocional diante de uma situação imprevista merece consideração. Os critérios de impessoalidade e universalidade que caracterizam o trato ao indivíduo foram desenvolvidos a fim de favorecer a 
justiça pela preservação da igualdade e, com ela, da liberdade. No entanto, em- bora o jeitinho afronte a concepção de igualdade humana como igualdade perante a lei, ele propõe uma igualdade perante a vulnerabilidade humana: daí, talvez, o diminutive. (Borges, 2011, p. 136).

Estaríamos, então, diante de uma atitude antiética e seria o jeitinho a base para o comportamento corrupto?

Borges responde que "trata-se de uma ética sustentada na emoção e no reconhecimento de diferenças dentro das circunstâncias. É como se, desde o início do século $X X$, entendêssemos que as regras servem ao respeito às exceções. Assim, existe uma ética no jeitinho, cujo critério de avaliação depende dos fatores circunstanciais" ((Borges, 2011, p. 136).

O ponto central da análise da autora é o "jeito como o corpo se lança na situação", que não pode ser autoritário ou arrogante, expressando sempre o improviso a favor da solidariedade, "evitando o risco de abuso [em prol] de uma vantagem pessoal do solicitante sobre os outros".

\section{Borges relata um exemplo pessoal bastante elucidativo:}

Vinda de um congresso, estava eu em uma fila para compra de passagens em uma rodoviária, quando uma moça esbaforida chegou até mim dizendo que acabara de chegar de uma longa viagem e que o próximo ônibus que ela precisava pegar saía em poucos minutos, e, se não pegasse esse ônibus, precisaria esperar horas na rodoviária, solicitando então às pessoas da fila, entre elas eu, que a deixassem passar na frente de todos para comprar o seu bilhete. Ela convenceu todos com o seu jeito humilde, aparentemente sincero nas suas atribulações, e todos cedemos o lugar: concedemos um jeitinho. Poucos minutos depois, outra mulher chegou até mim com outro jeito: ela me olhava de cima para baixo e, demonstrando superioridade, contou uma história muito parecida com a da moça anterior solicitando passar na minha frente. O que ela ouviu foi um redundante "não, o lugar na fila é por ordem de chegada". Não concedi a ela um jeitinho. Por que concedi um jeitinho para a primeira e não para a segunda mulher? Em primeiro lugar, a primeira moça me tocou emocionalmente com um jeito específico: aparentava humildade, parecia sincera e realmente envolvida em uma situação difícil que não pôde antecipar. Assim, foi tratada como pessoa à qual foi concedido o jeitinho como exceção à regra. $\mathrm{O}$ jeito da segunda mulher dizia o contrário: ela parecia se sentir superior e com a intenção de tirar proveito da boa vontade de todos. Portanto, foi tratada como indivíduo e igualada pelo trato impessoal no respeito às regras. (Borges, 2011, p. 135

A autora conclui o relato, dizendo que "a emoção é lançada na situação por meio do comportamento. Esquemas musculares sob a forma de atitudes orientam a emoção, expressando o jeito. Em outras palavras, se a moça do exemplo tivesse se dirigido aos demais integrantes da fila de outro jeito, poderia não ter conseguido alcançar seu objetivo" (Borges, 2011, p. 137). 
O jeito que o corpo se lança para expressar emoções comunica de forma não verbal as intenções presentes numa dada situação e, no caso do jeitinho, implica em atitudes e posicionamentos corporais flexíveis, tanto de quem o solicita quanto de quem é solicitado. "A filosofia do jeito entende o sistema postural do corpo como um totem vivo, [...] transformando continuamente as forças adversas em favoráveis, aludindo ao "totem como contraponto do tabu, aquilo que é intransponível, ou seja, o jeitinho atua de forma quase mágica na transformação do tabu em totem, do intransponível ao realizável" (Borges, 2011, p. 140).

Para concluir, a autora afirma que "na situação de jeitinho, a responsabilidade da improvisação recai sobre alguém que o concede, produzindo na instituição um quantum de instabilidade, ao passo que, no respeito intransigente à regra, a responsabilidade recai sobre a instituição, que, afinal de contas, é "ninguém". Em ambos, existe a possibilidade de justiça e injustiça. É uma questão de escolha: esconder- se sob as regras ou interagir como pessoa" (Borges, 2011, p. 142).

Com isso, abre-se a discussão sobre pessoas que dizem "apenas cumpro as regas [ou ordens]", que pode dar margem a inúmeros tipos de injustiça e o outro "você sabe com quem está falando?", aludindo à personificação do poder ou ao poder auto atribuído, que se considera mais merecedor que outros em situações de relacionamento com instituições.

Sob o ponto de vista do estudo sobre o jeitinho brasileiro em suas duas facetas, a postura corporal pode ser um elemento diferencial.

\section{Gonzalez: o Jeitinho Brasileiro da Anistia à Comissão da Verdade}

González \& Lentz (2012) investigam os fundamentos e os possíveis resultados da Comissão da Verdade. Os autores atribuem ao jeitinho uma conotação negativa que teria sido responsável pela tramitação, em regime de urgência do Projeto de Lei 7376/10, resultando em pouco debate por parte da sociedade acerca da criação da Comissão e pelos avanços limitados que anteveem para com seus objetivos, descritos na lei que a criou, a saber: investigações e esclarecimentos sobre as violações aos direitos humanos, reconstrução da verdade histórica e promoção da reconciliação nacional.

Dizem eles que "um dos problemas centrais da comissão está no próprio conceito de verdade. A ideia de uma verdade única, incontestável somente é compatível com uma visão religiosa, ou uma concepção positivista de direito. A verdade processual, que é a possível alcançar por meio de investigação documental e testemunhal, é uma verdade formal, procedimental, mas sujeita à interpretação, seja a dada pelo analista dos documentos, ou seja, a comissão, 
seja pelo leitor de suas conclusões, que pode aceitar ou recusar esta interpretação" (González \& Lentz, 2012, p. 137).

A possibilidade de interpretações sobre a verdade, aliada à apatia e alienação da sociedade para com os resultados da Comissão, dá espaço para que os autores desacreditem de sua efetividade quanto à reconciliação nacional ou perdão mútuo com superação de traumas.

Os autores também se mostram céticos com relação a eventuais avanços na democracia brasileira, em função de pesquisas recentes, citadas por eles, dando conta da valorização positiva da tortura para promoção da segurança pública e da aceitação do autoritarismo como solução para problemas nacionais (González \& Lentz, 2012, p. 138).

Embora o artigo não explicite a relação entre o jeitinho brasileiro e as investigações da Comissão da Verdade, é possível deduzir de sua leitura que este traço cultural permeou a formação da Comissão e tem potencial para impactar seus resultados.

\section{O Jeitinho, a Cultura Organizacional e a Cultura Nacional}

Nesse estudo, parte-se do pressuposto de que os princípios universais do cooperativismo não são suficientes para estabelecerem vínculos identitários entre seus membros, recorrendo-se aos valores da cultura brasileira para estabelecer laços de sociabilidade. Segundo os autores, pode-se afirmar que os princípios cooperativistas só teriam êxito à medida que o contexto cultural esteja mais próximo da democracia, especialmente a democracia participativa ou deliberativa (Pereira et al., 2013, p. 61).

A cultura de uma sociedade, segundo Bosi (1992, p.16, in Pereira et al., 2013), “é o conjunto das práticas, das técnicas, dos símbolos e dos valores que se devem transmitir às novas gerações para garantir a reprodução de um estado de coexistência social." A partir desse conceito pode-se observar a coexistência, em uma mesma sociedade, de variedades de culturas, tanto letradas como não letradas. Um grupo de pessoas dentro da sociedade pode formar um conjunto de valores específicos, ou seja, uma cultura própria, de modo que uma sociedade pode comportar grande diversidade cultural, como é o caso do Brasil.

A conduta de uma pessoa ou de um grupo de pessoas é orientada tanto pelos valores culturais quanto pela ideologia, sendo esta última um conjunto de crenças e ideias organizadas que induz um indivíduo ou um grupo à ação. Podese dizer que a cultura está relacionada à prática, ao hábito, enquanto a ideologia está relacionada às crenças, às ideias. Assim, a ideologia cooperativista está relacionada com os princípios cooperativistas e a cultura cooperativa com as práticas e os vínculos simbólicos estabelecidos entre os associados. Quando os 
associados apresentam valores culturais comuns, há identidade entre eles; quando os associados possuem ideias ou mesmo ideal de vida semelhantes, há identificação entre eles.

Fundamentada em Castoriadis, Freitas (1999, in Pereira et al., 2013, p. 66) considera que se pode compreender a sociedade e as organizações por meio de seu imaginário, definido por ela como "o espaço de representação, das formas e das imagens, a partir do qual é possível conceber o projeto, o desejo, a fantasia, o sonho de construir a si mesmo e o mundo". É assim que pelas significações imaginárias sociais pode-se responder o que somos como coletividade, o que nos faz diferentes e singulares como sociedade, e o que somos como sociedade no mundo.

As organizações, como produto da sociedade, expressam seu imaginário por meio de sua cultura organizacional. Ao levar em conta essas considerações, Freitas (1999) analisa as organizações como instituição e se apoia em Enriquez (1997) para qualificar a cultura organizacional como um sistema que é ao mesmo tempo cultural, simbólico e imaginário. Para Freitas (1999, in Pereira et al., 2013), “as organizações leem o que se passa em seu ambiente e (re) elaboram respostas que sirvam a seus objetivos. São espaços controlados de comportamento, ou seja, é de sua natureza controlar e direcionar a ação". No imaginário organizacional moderno apresentam-se as ideias de empresa- cidadã, culto da excelência, lugar da juventude eterna, ética e moralidade, comunidade, que são analisadas e desconstruídas pela autora. Para ela, são as organizações que estão ocupando os espaços de mediação das relações sociais: "os laços e as filiações identitárias se deslocam do social para o organizacional." (Freitas, 1999, in Pereira et al., 2013).

No artigo de Pereira et al. (2013), fica evidenciada a influência da cultura nacional brasileira, incluindo o jeitinho como um de seus traços característicos, nos processos organizacionais. Nesse sentido, os autores não atribuem uma conotação - positiva ou negativa - para o jeitinho.

\section{O Jeitinho Brasileiro e a Criatividade}

Conforme mencionado anteriormente, a criatividade pode resultar da combinação de elementos (Barlach, 2009). Supõe-se que, quanto mais díspares os componentes, maior será a criatividade da resultante, o que poderia explicar uma das vertentes do jeitinho brasileiro, a saber, a enorme criatividade associada à brasilidade.

As ciências naturais, como a química e a biologia, exploram amplamente este aspecto do conceito, ao analisar determinadas reações capazes de gerar sínteses a partir das quais os elementos passam a não mais ser reconhecíveis. 0 exemplo clássico é da água, resultante da combinação de hidrogênio e oxigênio, na qual já não se identificam - a olho nu - esses componentes. Na química e, por vezes também na genética, a mudança transforma elementos e, a partir da 
mudança, são alteradas suas propriedades fundamentais; gera-se um conjunto distinto de propriedades a partir da combinação. Mesmo quando os elementos se repetem, a própria condição de estarem combinados altera significativamente as propriedades e os elementos iniciais transformam-se em outros seres.

A postura corporal, muitas vezes denominada "jinga" brasileira, aliada à valorização da pessoa em detrimento do indivíduo, são dois dos elementos que, uma vez combinados, não mais são reconhecidos individualmente, constituindo um jeitinho singular, único, associado à brasilidade.

Da mesma forma, o sincretismo religioso e a miscigenação de povos que compõem a brasilidade não mais permite que se reconheça o cristianismo original ou a raiz tipicamente

A teoria da Gestalt também pode contribuir para entender o jeitinho, em função de estudar a criatividade no processo da adaptação humana em sua dependência da produção de novos significados a partir da flexibilização e diferenciação da figura com relação ao fundo ou contexto e vice-versa. Os (as) estrangeiros (as) que vêm ao País e os (as) estudiosos (as) que tomam a Etnografia como base precisam descentrar o olhar, tornando estranho o conhecido, alterando, necessariamente, a relação figura - fundo anteriormente existente.

A Gestalt considera que a criatividade provém do fato de que estas novas sínteses derivam de campos anteriormente independentes ou afastados e que, a partir de então, torna-se difícil reconhecê-los separadamente (Koestler, 1964). Este autor cunhou o termo bissociação para se referir às características de independência e autonomia das matrizes que são colocadas em contato pelo ato criativo, contrapondo-o ao pensamento associativo, que operaria entre membros de uma só matriz pré-existente. Um ato criativo envolve um código individual que desvia das regras convencionais - uma nova maneira de bissociar meios e motivos.

Quanto à adaptação humana e considerando a tensão entre a pessoa e seu meio ambiente, a psicologia da Gestalt entende sucessivos estágios de diferenciação e integração para a auto expansão e a auto realização, sendo esta última o "motivo soberano do organismo, [...] a tendência criativa da natureza humana na qual a pessoa desvela seu potencial para o campo do atual" (Smith, 2007 , p. 6 e 7). Atualizar, aqui, tem o sentido de viver o aqui-e-agora e relacionase à saúde mental, em contraposição a fixações e cristalizações seja para com a figura, seja para com o fundo, que caracterizariam a neurose. Autonomia ou autodeterminação - expansão do organismo pela assimilação e domínio cada vez maior de seu ambiente e homonomia ou entrega - ajustar-se ao ambiente e participar de algo maior que o self, são os dois componentes da adaptação criativa. 
A teoria da Gestalt refere-se ao ajustamento criativo adicionando a noção de mutualidade neste ajustamento, a partir de uma perspectiva de campo. Neste sentido, o ajustamento vem a ser um dar-e-receber, podendo o indivíduo alterar o ambiente - até refazê-lo ou criá-lo diferentemente - assim como mudar a si mesmo para se encaixar nele (Barlach, 2009, p. 64).

Este é o principal aspecto que explicaria o jeitinho brasileiro em sua vertente criativa, se contraposta à sua versão corrupta. Nas palavras de Latner, o ajustamento criativo implica "usar a competência e a energia para estender a fronteira do que é possível em qualquer campo da vida e em qualquer nível de complexidade" (Latner, 2003, p. 74). Vida saudável é permeada de improvisação, composta de um ato criativo após o outro, ao passo que neurose é o aprisionamento a padrões repetitivos e inflexíveis.

Uma abordagem psicossocial da criatividade desvenda a conexão intrínseca entre $o$ ato criativo e a cultura o que, por um lado, revitaliza permanentemente este ato, mas, por outro, concede a este o estatuto da subjetividade, impossibilitando generalizações que extrapolem a subjetividade compartilhada que é a cultura.

É importante observar que cada cultura tem uma concepção própria do ato criativo (Lubart, 2007), estabelecendo critérios do que seja criativo. Também a promoção ou proibição da atividade criativa é impactada por variações culturais, segundo a importância dada ao indivíduo ou à coletividade (na cultura individualista, o indivíduo é considerado um autônomo e independente, ao passo que, nas culturas coletivistas, a pessoa é sempre pensada em relação a seu contexto social). A cultura influencia o modo pelo qual o indivíduo vai procurar se diferenciar de outros membros de sua comunidade e adotar condutas mais ou menos conformes às regras comuns, remetendo à dimensão individualismo coletivismo e ao lugar ocupado pelo respeito às tradições. Em certas culturas há maior permissão para a expressão de condutas que se afastam das normas tradicionais.

Nesse contexto, o jeitinho brasileiro pode ser pensado como forma de diferenciação da pessoa com relação ao indivíduo, massificador e universalizante, e entendido como forma de singularização diante das macroestruturas sociais.

A partir de um enfoque psicossocial, é possível afirmar que a criatividade é um conceito antônimo ao das estereotipias, conformismos e dogmatismos. Segundo Sassenberg \& Moskowitz (2005), "ser criativo implica a tentativa de evitar as rotas convencionais de pensar e, portanto, evitar a ativação de associações típicas" (p. 507). É nesse sentido que se pode considerar o jeitinho brasileiro como um dos elementos que caracteriza como criativa a identidade nacional. 


\section{Referências Bibliográficas}

Barbosa, Livia. (2006). O jeitinho brasileiro: a arte de ser mais igual do que os outros. RJ: Elsevier.

Barlach, Lisete. (2009). "A criatividade humana sob a ótica do empreendedorismo inovador". Tese de Doutorado. SP: IPUSP.

Borges, Fernanda Carlos. (2011). “'A improvisação no jeitinho brasileiro". Trama Interdisciplinar - v. 2 - n. 1.

Da Matta, Roberto. Carnavais, malandros e heróis. RJ: Rocco, 1997.

González, Rodrigo Stumpf., \& Lentz, Rodrigo. (2012). “Qual será a verdade do jeitinho brasileiro? Perspectivas sobre a Comissão Nacional da Verdade do Brasil'. Ciências Sociais Unisinos, 48(2): 130-138.

Koestler, Arthur. Act of creation. London: Penguin Books, 1964.

Latner, Joel. (2003). “America's Protean Creativity: Gestalt Therapy and Creative License - essay and book review". International Gestalt Journal, v. 28, n. 2, p. 67-122.

Leichsenring, Ivan M. F. (2014). "A universidade corrupta: o jeitinho brasileiro de se fazer ciência". Revista Espaço Acadêmico, n. 152.

Lubart, Todd. Psicologia da criatividade. Porto Alegre: Artmed, 2007. 192 p.

Oliveira, Amurabi. (2011). "A nova era com um jeitinho brasileiro: o caso do vale do Amanhecer". Debates do NER, Porto Alegre, ano 12, n. 20 p. 67-95.

Oliveira, Tânia Modesto Veludo de., \& Aguiar, Fernando Henrique Oliveira de., \& Queiroz, Josimeire Pessoa de., \& Barrichello, Alcides. (2014). “Cola, plágio e outras práticas acadêmicas desonestas: um estudo quantitativo-descritivo sobre o comportamento de alunos de graduação e pós-graduação da área de negócios". RAM, Revista Administração Mackenzie, vol.15 no.1 São Paulo.

Pereira, José Roberto., \& Cançado, Airton Cardoso., \& Rodrigues, Flávia Oliveira., \& Silva, Edmilson Eduardo. (2013). "Cultura organizacional e cultura brasileira: compreendendo as fragilidades do cooperativismo brasileiro". Revista NAU Social - v.4, n.6, p. 61-81.

Pereira, Beatriz. (2008). “Pesquisa etnográfica em MKT”. Mestrado, FEA.

Pezzia, Agustin Espinosa. (2010). Estudios sobre identidad nacional en el peru y sus correlatos psicologicos, sociales y culturales". Tesis Doctoral. Universidad del Pais Vasco, San Sebastián, Peru. 
Queiroz, Maria Isaura Pereira de. (1989). "Identidade Cultural, Identidade Nacional no Brasil". Tempo Social - Rev. Sociologia da USP. S. Paulo, 1(1), 10 sem..

Sassenberg, Kai., \& Moskowitz, Gordon. (2005). 'Don't stereotype, think differently! Overcoming automatic stereotype activation by mindset priming". Journal of Experimental Social Psychology, v. 41, p. 506-514.

Smith, Edward W. L. (2007). "Art, artists and the Gestalt approach: an introduction". The International Gestalt Journal, v. 30, n. 2, p. 1-26, Fall.

Souza, Gustavo Henrique Silva de., \& Coelho, Jorge Artur Peçanha de Miranda., \& Lima, Nilton Cesar., \& Queiroz, Jamerson Viegas. (2014). “Marketing informal: um modelo de comercialização pautado em jeitinho brasileiro, informalidade e empreendedorismo". Revista Brasileira de Marketing - ReMark, Vol. 13, N. 3.

Vieira, Clóvis Abreu., \& Costa, Frederico Lustosa da., \& Barbosa, Lázaro Oliveira. (1982). "O "jeitinho" brasileiro como um recurso de poder". Revista de Administração Pública, Rio de Janeiro, 16(2):5-31.

Zawislak, Paulo Antonio. (2014). "Gestão da inovação tecnológica e competitividade: industrial: uma proposta para o caso brasileiro". Organizações \& Sociedade. 